\title{
Electrophysiology and nerve biopsy in men exposed to lead
}

\author{
F. BUCHTHAL ${ }^{1}$ AND F. BEHSE \\ From the Institute of Neurophysiology, University of Copenhagen, the Laboratory of Clinical \\ Neurophysiology and the Research Laboratories of the Rigshospital, Copenhagen
}

ABSTRACT Twenty lead-exposed men were selected on the basis of a maximum level of lead in the blood of $70-140 \mu \mathrm{g} / 100 \mathrm{ml}$ within the past year. There was no clinical evidence of neuropathy attributable to lead and haemoglobin levels were normal. In individuals, maximum motor and sensory conduction and the amplitude of the evoked potentials were normal or borderline in the median, peroneal and sural nerves, except in the distal portion of the deep peroneal nerve. In this nerve, motor conduction was slowed because of compression by metal-lined safety shoes; changes in this segment are not included in the findings. When the average conduction velocity in lead-exposed men was compared with the average in nerves of controls matched for age, distal motor latency was slightly prolonged in the median nerve. The average latency for proximal muscle supplied by the peroneal nerve was prolonged, and the maximum motor conduction velocity was slowed in the median nerve from elbow to wrist $(0.01>P<0.001)$. In addition, the average maximum sensory conduction was slightly slowed along the distal and intermediate portions of the median nerve and the intermediate portion of the superficial peroneal and sural nerves $(P<0.001)$. The average minimum sensory conduction velocities were normal, as were the average amplitudes of the evoked muscle action potentials and the average ratio of amplitude of the muscle action potential evoked by stimuli at a proximal and a distal nerve site. The average amplitude of the sensory potentials recorded in the median and the superficial peroneal nerves tended to be increased. Electromyography of the abductor pollicis brevis and anterior tibial muscles showed that the only abnormality was an increased incidence of polyphasic potentials in the anterior tibial muscle of seven men. Neither the slowing in conduction nor the histological findings in the sural nerves of eight men were related to the level of lead in the blood. The slight slowing in conduction suggests a minor defect in the excitable membrane of the nerve fibre: it was not attributable to histological abnormalities in the sural nerve, in which the number of myelinated and unmyelinated nerve fibres was normal and demyelination was absent. In teased fibres, those with paranodal remyelination were slightly increased, and few fibres had segments with diminished diameter. The mechanism of the defect causing the slight slowing in conduction in lead-exposed men seems to differ from the lesion in patients with clinical evidence of lead neuropathy, which is axonal in type. It is, therefore, doubtful whether the slight slowing in the nerves of the group of lead-exposed men should be classified as a subclinical neuropathy.

Although chronic lead poisoning from industrial exposure is still an occupational hazard, its incidence has decreased. Paralysis of the extensor muscles of the forearm, which used to be common, is now extremely rare. It is not known what is the lowest concentration of blood lead associated with damage

'Present address: Rigshospitalet, Section 4112, Copenhagen, Denmark 2100.

Received for publication 10 May 1978 Accepted for publication 6 July 1978 to peripheral nerves, but clinical symptoms and signs attributable to peripheral nerve damage do not occur with blood lead levels below $90-100 \mu \mathrm{g} / 100 \mathrm{ml}$ in adults. Catton et al. (1970) reported slight electrophysiological abnormalities in motor fibres of the peroneal nerve in lead-exposed subjects. Blood levels were at least $80 \mu \mathrm{g} / 100 \mathrm{ml}$ and there was often a low haemoglobin concentration. The maximum conduction velocity was normal. In lead-exposed subjects with blood levels below the commonly accepted safety norm $(70 \mu \mathrm{g} / 100 \mathrm{ml})$ two later studies reported 
a slight reduction in maximum motor conduction velocity along the median and the ulnar nerves by 4 and $3 \mathrm{~m} / \mathrm{s}$ respectively (Seppäläinen and Hernberg, 1972; Seppäläinen et al., 1975), and along the motor fibres of the tibial nerve (Araki and Homma, 1976). The latter authors found that the degree of conduction retardation depended on the concentration of lead in the blood.

Our study was motivated by the fact that one group of workers found normal maximum conduction velocity at blood levels exceeding $80 \mu \mathrm{g} / 100 \mathrm{ml}$ (Catton et al., 1970), while others found slight slowing when maximum blood levels were 50-70 $\mu \mathrm{g} / 100$ ml (Seppäläinen et al., 1975; Araki and Homma, 1976). We have examined 20 lead-exposed subjects with maximum levels of $50-144 \mu \mathrm{g} / 100 \mathrm{ml}$ blood. Because the slowing in conduction found previously was slight, and was significant only when the subjects were taken as a group, we determined motor and sensory conduction velocities and motor latencies for, in all, 12 different nerves or portions of the same nerve. Moreover, as histological examination of nerve is a more sensitive indicator of neuropathy than nerve conduction (Behse and Buchthal, 1978), biopsies were obtained from the sural nerve of eight subjects. Electrophysiological and histological findings were compared with those in controls and in a patient with clinical evidence of lead neuropathy.

\section{Material and methods}

\section{SUBJECTS}

Twenty men employed in a lead smelting and refining factory for four months to 33 years volunteered to take part. Seventeen of the 20 had more than one year's exposure to lead. The mean age was 34 years ranging from 23 to $60 \mathrm{yr}$. All but one subject had been found to have a blood lead level exceeding 70 $\mu \mathrm{g} / 100 \mathrm{ml}$ during the previous year.

None of the men were anaemic or were suffering from any disease predisposing to peripheral neuropathy. Heavy drinkers were excluded from the study. However, two men with signs of clinical neuropathy, who were employed in the same factory, were included.

\section{METHODS}

\section{Neurological examination}

Muscle force was tested by the same experienced physiotherapist. Perception of light touch and of pin-prick was tested by one stimulus and by two simultaneous stimuli (Bender, 1952, 1970). Vibratory sense was quantified by measuring the length of time during which a vibrating tuning fork was perceived, and position sense was also tested.

\section{Electromyography}

Electromyography was carried out on the anterior tibial and abductor pollicis brevis muscles, and in two patients with diminished force in one to three additional muscles. The findings were quantified as described by Buchthal (1957) and compared with findings in normal subjects (Rosenfalck and Rosenfalck, 1975).

\section{Nerve conduction}

Maximum motor conduction velocity and motor latency were determined along four portions of the peroneal and two portions of the median nerve (Fig. 1). The muscle action potentials were recorded by a non-insulated steel wire, $80 \mu \mathrm{m}$ in diameter, inserted for a length of $5-10 \mathrm{~mm}$ in the end-plate zone of the muscle (Wagner and Buchthal, 1972). To eliminate the large scatter in absolute amplitude of the muscle action potentials, the amplitude following stimulation of the nerve at the head of the fibulae was expressed as a percentage of that following stimulation at the ankle, and the amplitude recorded at the elbow was expressed as a percentage of that following stimulation at the wrist (Catton $e t$ al., 1970).

Maximum sensory conduction velocity was determined along the sural and superficial peroneal nerves and along four portions of the median nerve (Fig. 1). The sensory potentials were led off through needle electrodes and recorded at a surface temperature of $35-36^{\circ} \mathrm{C}$. The minimum sensory conduction velocity, determined from the latency of the initial positive peak of the slowest component, was recorded by electronic averaging of 250 and 500 responses (Buchthal and Rosenfalck, 1966, 1971; Dahl and Buchthal, 1978).

\section{Statistical evaluation}

The findings in lead-exposed men were compared with those in a large series of controls matched for age (Behse and Buchthal, 1971; Rosenfalck and Rosenfalck, 1975). Motor and sensory conduction velocities seemed to be normally distributed. The distribution of the amplitudes of the evoked potentials was skew and a Gaussian function could not properly be used. Instead, the logarithm of amplitude was used; this was distributed symmetrically and was assumed to be normal. The regressions of conduction velocities and amplitudes as a function of age were calculated by the method of least squares. The equations of the regressions and the variation about the regression lines are given in Buchthal et al., 1975 and Rosenfalck and Rosenfalck, 1975. To evaluate the statistical significance, the difference was taken between the value observed in the lead-exposed men and that obtained from the regressions of the 


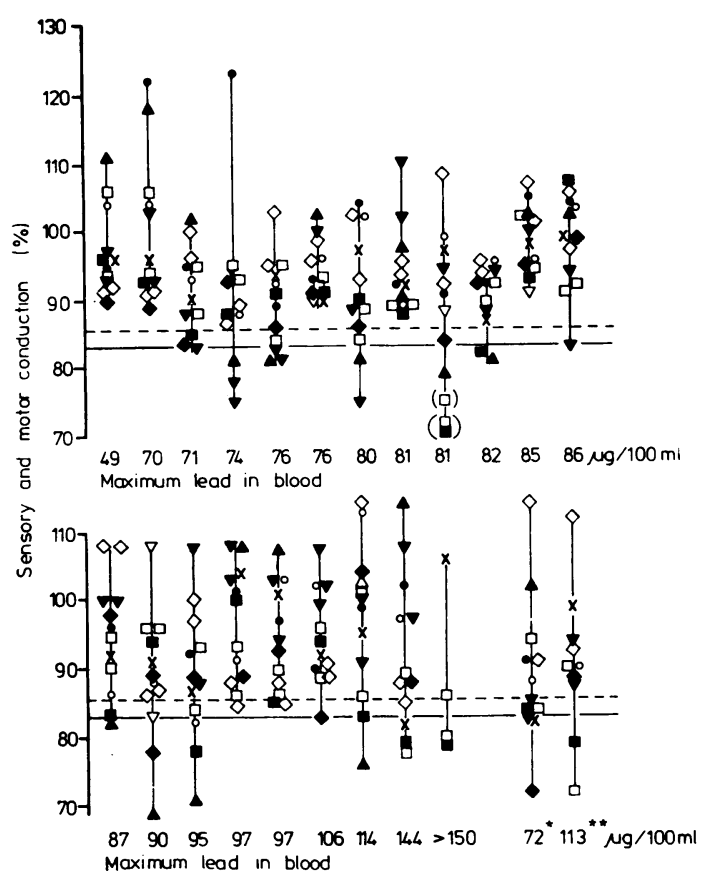

Fig. 1 Sensory and motor conduction in the different nerves of each lead-exposed man. Each vertical line connects findings in one man. The maximum conduction velocity is given as a percentage of the normal average matched for age; motor latencies are corrected to a standard distance and given as reciprocal latencies. The figures below each vertical line indicate the maximum level of lead in the blood monitored within the past year. The value in the patient with lead neuropathy, indicated by $>150$, was extrapolated from urinary lead and coproporphyrin. Below, right: * excluded because of multiple joint swellings; ** excluded because of chronic alcoholism. ( ) data from the median nerve in the patient with the carpal tunnel syndrome. The full horizontal line represents the lower $95 \%$ confidence limit for motor conduction and the dashed line for sensory conduction. Motor nerves: median, elbowwrist ( ), wrist-m. abductor pollicis brevis ( $\square)$; peroneal, capitulum fibulae-ankle (O); capitulum fibulae $m$. tibialis anterior and $m$. peroneus longus $(\nabla)$; ankle-m. extensor digitorum brevis ( $\mathbf{\Delta})$. Sensory nerves: median, wrist-elbow (stimuli to digit I and digit III) $(\diamond)$, digit I and digit III-wrist $(\square)$; superficial peroneal nerve, retinaculum superior-capitulum fibulae (O); sural nerve, lateral malleolus-midcalf $(\mathrm{X})$.

variates on age in controls. A $t$-test was used to assess the null hypothesis, i.e. that there is no difference between the means of conduction velocities and amplitudes in lead-exposed men and in controls matched for age. Two-sided significance limits were used to compare the probabilities.
Nerve biopsy

Thirty $\mathrm{mm}$ of the sural nerve were removed in toto just proximal to the lateral malleolus in eight leadexposed men and in two patients with neuropathy. The preparation of the specimen for light and electron microscopy and the teasing of $10 \mathrm{~mm}$ of each of 50 fibres have been described elsewhere (Behse et al., 1972, 1974; Behse and Buchthal, 1977). Findings on light microscopy were compared with those in 10 nerves from controls (18-59 years old); findings on electron microscopy were compared with six nerves from controls (18-47 years old), and findings in teased fibres were compared with those of seven nerves from controls (15-54 years old).

\section{Determination of lead in the blood}

Blood (2-5 ml) was obtained by venous puncture with lead-free needles in sampling tubes that contained less than $0 \cdot 1 \mu \mathrm{g}$ lead. The tubes were prepared with a lead-free anticoagulant (heparin or EDTA).

The blood levels of lead were monitored every 2-3 months. In the first eight lead-exposed men of the series the lead levels in the blood were determined by the following three laboratories (for an evaluation of different methods see Pierce et al., 1976): (i) MediLab. Inc, Copenhagen, Denmark used a 'carbon furnace atomic absorption' method (Fernandez, 1975), a Perkin-Elmer atomic absorption photometer, model 400, and a Perkin-Elmer graphite furnace model HGA 74. The standard deviation in duplicate determinations, determined on 140 samples, was $1.8 \mu \mathrm{g} / 100 \mathrm{ml}$ (variation coefficient $4.4 \%$ ) (P. Persson, personal communication); (ii) Environmental Sciences Associates Inc, Bedford, Massachusetts, USA used anodic stripping voltammetry (Matson et al., 1965; US Department of Health, Education and Welfare, 1977). In the range of concentrations examined in this study, duplicate determinations had a standard deviation of $2.9 \mu \mathrm{g} /$ $100 \mathrm{ml}$ (17 samples) (variation coefficient $4.3 \%$ ) (R. M. Griffin, personal communication); (iii) National Occupational Hygiene Service Limited, Manchester, England used a modified punched disc technique (Cernik and Sayers, 1971; Cernik, 1974), the modifications being that Whatman 41 papers and a high-speed recorder were used. An example of a typical standard deviation in the range of concentrations of $20-80 \mu \mathrm{g} / 100 \mathrm{ml}$ (50 triplicate samples) was $1.80 \mu \mathrm{g} / \mathrm{ml}$. The variance within samples (longterm repeatability) was $2 \cdot 8 \mu \mathrm{g} / 100 \mathrm{ml}$ (E. King, personal communication).

As the lead content in the blood of the 24 samples showed satisfactory agreement within the variability of lead determinations, the blood levels of the subsequent fourteen lead-exposed men were determined either by Medi-Lab. or by the National 
Occupational Hygiene Service.

Results

\section{NEUROLOGICAL FINDINGS}

None of the 20 lead-exposed men had a history of previous neurological disease or complained of any of the effects attributable to chronic exposure to large amounts of lead, such as fatigue, loss of appetite, headache, tremor, loss of memory or constipation. There was no weakness and no wasting in the muscles of the extremities, and flexion and extension of the neck were performed with normal force. Discrete neurological abnormalities were found in seven men but can hardly be considered evidence of neuropathy; they were neither related to the level of lead in the blood nor to a history of colic, present in four men. One of these men had a high level of lead $(144 \mu \mathrm{g} / 100 \mathrm{ml})$ at the time of the colic. The concentration of haemoglobin in the blood was normal except in the patient with lead neuropathy, in whom it was diminished.

\section{ELECTROMYOGRAPHY}

Abnormalities were few and unimportant diagnostically. There was an increased incidence of polyphasic potentials in the abductor pollicis brevis muscle in one man and in the anterior tibial muscle in seven of 20 men; this increased incidence was associated with a prolonged distal latency in four of these men. There were no fibrillation potentials or positive sharp waves in any of the 39 muscles examined. The potential duration of 30 motor unit potentials sampled in each muscle was normal, as were the pattern and amplitude during full effort.

\section{NERVE CONDUCTION}

\section{Findings in the individual lead-exposed man}

With the exception of distal motor latency in the deep peroneal nerve, motor and sensory conduction and the amplitude of the evoked muscle action potentials and of the sensory potentials were normal or borderline (Fig. 1). The distal motor latency in the peroneal nerve was prolonged in eight of 20 men (at most $31 \%$ ); the maximum motor conduction velocity along the proximal segment, from capitulum fibulae to ankle, was normal in all. The ratio of the amplitudes of the muscle action potentials was diminished in three men when the median nerve was stimulated and in four men when the deep peroneal nerve was stimulated $(<85 \%)$. Findings in the median nerve were excluded in one man because he had evidence of a carpal tunnel syndrome, comprising slowed distal motor and sensory conduction, normal proximal sensory conduction along the median nerve and normal

Table 1 Mean nerve conduction in lead-exposed men and controls, matched for age

\begin{tabular}{|c|c|c|c|c|c|c|}
\hline \multirow[t]{2}{*}{ Nerve } & \multicolumn{2}{|c|}{ Lead-exposed men } & \multirow{2}{*}{$\begin{array}{l}\text { Controls* } \\
\text { (Mean) }\end{array}$} & \multicolumn{2}{|l|}{ Difference } & \multirow{2}{*}{$\begin{array}{l}\text { Significance } \\
(P)\end{array}$} \\
\hline & (No.) & (Mean) & & (Mean) & $(S D)$ & \\
\hline \multicolumn{7}{|l|}{ Motor } \\
\hline $\begin{array}{l}\text { Median nerve } \\
\text { Wrist-m.abductor pollicis brevis } \ddagger \\
\text { Elbow-wrist }\end{array}$ & $\begin{array}{l}19 \\
19\end{array}$ & $\begin{array}{c}3.2 \mathrm{~ms} \\
58 \cdot 1 \mathrm{~m} / \mathrm{s}\end{array}$ & $\begin{array}{c}2.8 \mathrm{~ms} \\
63.6 \mathrm{~m} / \mathrm{s}\end{array}$ & $\begin{array}{c}0.39 \mathrm{~ms} \\
-5.50 \mathrm{~m} / \mathrm{s}\end{array}$ & $\begin{array}{l}0.23 \mathrm{~ms} \\
4.03 \mathrm{~m} / \mathrm{s}\end{array}$ & $\begin{array}{l}<0.001 \\
<0.001\end{array}$ \\
\hline $\begin{array}{l}\text { Peroneal nerve } \\
\text { Ankle-m.extensor digitorum brevis } \S \\
\text { Capitulum fibulae-ankle } \\
\text { Capitulum fibulae-m.tibialis anterior } \uparrow \\
\text { and -m.peroneus longus } \uparrow\end{array}$ & $\begin{array}{l}20 \\
20 \\
40\end{array}$ & $\begin{array}{c}4.5 \mathrm{~ms} \\
50 \cdot 1 \mathrm{~m} / \mathrm{s} \\
3.2 \mathrm{~ms}\end{array}$ & $\begin{array}{c}3.9 \mathrm{~ms} \\
51.0 \mathrm{~m} / \mathrm{s} \\
3.0 \mathrm{~ms}\end{array}$ & $\begin{array}{c}0.67 \mathrm{~ms} \\
-0.90 \mathrm{~m} / \mathrm{s} \\
0.20 \mathrm{~ms}\end{array}$ & $\begin{array}{l}0.77 \mathrm{~ms} \\
5.15 \mathrm{~m} / \mathrm{s} \\
0.32 \mathrm{~ms}\end{array}$ & $\begin{array}{l}<0.001 \\
\text { NS } \\
<0.001\end{array}$ \\
\hline \multicolumn{7}{|l|}{ Sensory } \\
\hline $\begin{array}{l}\text { Median nerve } \\
\text { Digit I-wrist } \\
\text { Digit III-wrist } \\
\text { Digit III-wrist, minimum velocity } \\
\text { Wrist-elbow (Digit I) } \\
\text { Wrist-elbow (Digit III) }\end{array}$ & $\begin{array}{l}19 \\
19 \\
19 \\
20 \\
20\end{array}$ & $\begin{array}{l}48.5 \mathrm{~m} / \mathrm{s} \\
56.2 \mathrm{~m} / \mathrm{s} \\
14.9 \mathrm{~m} / \mathrm{s} \\
63.7 \mathrm{~m} / \mathrm{s} \\
63.9 \mathrm{~m} / \mathrm{s}\end{array}$ & $\begin{array}{l}54.5 \mathrm{~m} / \mathrm{s} \\
61.2 \mathrm{~m} / \mathrm{s} \\
16.0 \mathrm{~m} / \mathrm{s} \\
67.1 \mathrm{~m} / \mathrm{s} \\
67.2 \mathrm{~m} / \mathrm{s}\end{array}$ & $\begin{array}{l}-5.96 \mathrm{~m} / \mathrm{s} \\
-5.05 \mathrm{~m} / \mathrm{s} \\
-1.09 \mathrm{~m} / \mathrm{s} \\
-3.40 \mathrm{~m} / \mathrm{s} \\
-3.36 \mathrm{~m} / \mathrm{s}\end{array}$ & $\begin{array}{l}3.33 \mathrm{~m} / \mathrm{s} \\
3.36 \mathrm{~m} / \mathrm{s} \\
4.40 \mathrm{~m} / \mathrm{s} \\
5.09 \mathrm{~m} / \mathrm{s} \\
4.87 \mathrm{~m} / \mathrm{s}\end{array}$ & $\begin{array}{l}<0.001 \\
<0.001 \\
\text { NS } \\
<0.01 \\
<0.01\end{array}$ \\
\hline $\begin{array}{l}\text { Superficial peroneal nerve } \\
\text { Retinaculum superior-capitulum fibulae }\end{array}$ & 20 & $53.0 \mathrm{~m} / \mathrm{s}$ & $55.5 \mathrm{~m} / \mathrm{s}$ & $-2.51 \mathrm{~m} / \mathrm{s}$ & $4.50 \mathrm{~m} / \mathrm{s}$ & $<0.025$ \\
\hline $\begin{array}{l}\text { Sural nerve } \\
\text { Malleolus lateralis-midcalf } \\
\text { Malleolus lateralis-midcalf, minimum } \\
\text { velocity }\end{array}$ & $\begin{array}{l}20 \\
19\end{array}$ & $\begin{array}{l}50.7 \mathrm{~m} / \mathrm{s} \\
13.3 \mathrm{~m} / \mathrm{s}\end{array}$ & $\begin{array}{l}54.6 \mathrm{~m} / \mathrm{s} \\
15.0 \mathrm{~m} / \mathrm{s}\end{array}$ & $\begin{array}{l}-3.83 \mathrm{~m} / \mathrm{s} \\
-1.65 \mathrm{~m} / \mathrm{s}\end{array}$ & $\begin{array}{l}2.98 \mathrm{~m} / \mathrm{s} \\
4.53 \mathrm{~m} / \mathrm{s}\end{array}$ & $\begin{array}{l}<0.001 \\
\text { NS }\end{array}$ \\
\hline
\end{tabular}

Obtained from the regressions of nerve conduction as a function of age. $\nmid N S$ : not significant. Corrected to a standard distance $¥$ of $6.5 \mathrm{~cm}$, $\$ 0 f 9.0 \mathrm{~cm}$ and Tof $10.0 \mathrm{~cm}$ (Wagner and Buchthal, 1972). 
Table 2 Mean amplitude of evoked potentials in lead-exposed men and controls, matched for age

\begin{tabular}{|c|c|c|c|c|c|c|}
\hline \multirow[t]{2}{*}{ Nerve } & \multicolumn{2}{|c|}{ Lead-exposed men } & \multirow{2}{*}{$\begin{array}{l}\text { Controls* } \\
\text { (Mean) }\end{array}$} & \multicolumn{2}{|c|}{ Log difference } & \multirow{2}{*}{$\begin{array}{l}\text { Significance } \dagger \\
(P)\end{array}$} \\
\hline & (No.) & (Mean) & & (Mean) & $(S D)$ & \\
\hline \multicolumn{7}{|l|}{ Motor } \\
\hline \multicolumn{7}{|l|}{ Median nerve } \\
\hline $\begin{array}{l}\text { M.abductor pollicis brevis, stimulus at } \\
\text { wrist }\end{array}$ & 19 & $13.4 \mathrm{mV}$ & $14.9 \mathrm{mV}$ & $-0.09 \mathrm{mV}$ & $0.19 \mathrm{mV}$ & NS \\
\hline $\begin{array}{l}\text { M.abductor pollicis brevis, stimulus at } \\
\text { elbow }\end{array}$ & 19 & $11.6 \mathrm{mV}$ & $11.0 \mathrm{mV}$ & $-0.02 \mathrm{mV}$ & $0.18 \mathrm{mV}$ & NS \\
\hline \multicolumn{7}{|l|}{ Peroneal nerve } \\
\hline $\begin{array}{l}\text { M.extensor digitorum brevis, stimulus } \\
\text { at ankle }\end{array}$ & 20 & $10.0 \mathrm{mV}$ & $10.0 \mathrm{mV}$ & $-0.01 \mathrm{mV}$ & $0.37 \mathrm{mV}$ & NS \\
\hline $\begin{array}{l}\text { M.extensor digitorum brevis, stimulus } \\
\text { at capitulum fibulae }\end{array}$ & 20 & $8.0 \mathrm{mV}$ & $8.0 \mathrm{mV}$ & $-0.06 \mathrm{mV}$ & $0 \cdot 24 \mathrm{mV}$ & NS \\
\hline $\begin{array}{l}\text { M.tibialis anterior and m.peroneus } \\
\text { longus, stimulus at capitulum fibulae }\end{array}$ & 40 & $14.5 \mathrm{mV}$ & $15.0 \mathrm{mV}$ & $-0.04 \mathrm{mV}$ & $0.15 \mathrm{mV}$ & NS \\
\hline \multicolumn{7}{|l|}{ Sensory } \\
\hline \multicolumn{7}{|l|}{ Median nerve } \\
\hline Wrist, stimulus to digit I & 19 & $39 \cdot 8 \mu \mathrm{V}$ & $35 \cdot 7 \mu \mathrm{V}$ & $0.05 \mu \mathrm{V}$ & $0 \cdot 20 \mu \mathrm{V}$ & NS \\
\hline Wrist, stimulus to digit III & 19 & $18 \cdot 1 \mu \mathrm{V}$ & $13.8 \mu \mathrm{V}$ & $0.12 \mu \mathrm{V}$ & $0.14 \mu \mathrm{V}$ & $<0.005$ \\
\hline Elbow, stimulus to digit I & 19 & $12 \cdot 0 \mu \mathrm{V}$ & $9 \cdot 8 \mu \mathrm{V}$ & $0.09 \mu \mathrm{V}$ & $0.18 \mu \mathrm{V}$ & $<0.05$ \\
\hline Elbow, stimulus to digit III & 19 & $7 \cdot 8 \mu \mathrm{V}$ & $6.4 \mu \mathrm{V}$ & $0.08 \mu \mathrm{V}$ & $0.23 \mu \mathrm{V}$ & NS \\
\hline \multicolumn{7}{|l|}{ Superficial peroneal nerve } \\
\hline $\begin{array}{l}\text { Capitulum fibulae, stimulus at } \\
\text { retinaculum superior }\end{array}$ & 20 & $5 \cdot 5 \mu \mathrm{V}$ & $3.6 \mu \mathrm{V}$ & $0 \cdot 22 \mu \mathrm{V}$ & $0.33 \mu \mathrm{V}$ & $<0.01$ \\
\hline \multicolumn{7}{|l|}{ Sural nerve } \\
\hline Midcalf, stimulus at malleolus lateralis & 20 & $11 \cdot 3 \mu \mathrm{V}$ & $10.7 \mu \mathrm{V}$ & $0.02 \mu \mathrm{V}$ & $0.28 \mu \mathrm{V}$ & NS \\
\hline
\end{tabular}

*Obtained from the regressions of log amplitude of the evoked potential as a function of age.

+ NS : not significant.

motor and sensory conduction along the ulnar nerve.

In none of the nerves examined was the incidence of borderline abnormalities or the value of conduction or amplitude of the evoked potential related to the maximum level or to the average level of lead in the blood, to the level at the time of the electrophysiological study, or to the duration of exposure to lead.

\section{Findings in the group of lead-exposed men}

Nerve conduction and amplitude of evoked potentials in motor and sensory nerves are summarised in Tables 1 and 2. The average motor latencies were longer and the average maximum motor conduction velocities slower in lead-exposed men than in controls. An exception was the normal conduction velocity along the deep peroneal nerve. The marked prolongation of the distal motor latency in half the peroneal nerves was probably caused by local compression of that nerve by safety shoes. The average ratio of the amplitudes of the muscle action potentials evoked by stimulation at a proximal and a distal site was the same in lead-exposed men as in controls.

Average maximum sensory conduction velocity was reduced in the segments examined of the median, peroneal and sural nerves. Despite this reduction, the average amplitude of the sensory potentials was, or tended to be, higher in lead-exposed men than in controls. The increase in amplitude of the pooled nerves, tested by the 'omnibus test' (Fisher. 1944), was highly significant, suggesting that the increase in amplitude was a general property of the nerves of the lead-exposed men.

In none of the motor or sensory nerves did the conduction velocity or the amplitude of responses differ when average values were compared in 10 men with a maximal concentration of lead in the blood of less than $85 \mu \mathrm{g} / 100 \mathrm{ml}$ and in 10 men with more than $85 \mu \mathrm{g} / 100 \mathrm{ml}$, corresponding to average blood levels of lead of less or more than $70 \mu \mathrm{g} / 100 \mathrm{ml}$.

TWO PATIENTS WITH SIGNS AND SYMPTOMS OF NEUROPATHY

\section{Patient $A$}

A 58-year-old man exposed to lead since the age of 45 years was the only patient who had clinical evidence of lead neuropathy. When 46 years old he complained of lassitude, colic and constipation. The blood count showed 12900 red cells per million with basophilic stippling, haemoglobin was $72 \mathrm{mmol} /$ litre $(7.9 \mathrm{mmol} /$ litre is the lower limit of normal in males). 
The urine contained $185 \mu \mathrm{g}$ lead/litre. In the next decade blood and urine were examined repeatedly, and gradually gave normal results.

At the age of 57 years, after working for seven months at a smelting furnace, he again complained of headache, nausea, vomiting, colic and constipation; the haemoglobin was $7.4 \mathrm{mmol} /$ litre; the blood count showed 9200 red cells per million with basophilic stippling; the urine contained $200 \mu \mathrm{g}$ lead/litre, 400$800 \mu \mathrm{g}$ coproporphyrin/litre and $9 \mathrm{mg} \delta$-aminolevulinic acid/litre. The urinary measurements and the amount of basophilic stippling indicate that blood levels of lead were probably excessive (Lane et al., 1968).

Neurological examination showed that tendon jerks were absent in the arms and legs; the mandibular reflex was normal. There was weakness in facial muscles and in muscles of the arms and legs, the force of elbow and neck flexion being half that of the normal average. Tactile sensibility and the perception of vibration and posture were normal.

Electromyography performed in the extensor digitorum communis and abductor pollicis brevis muscles showed fibrillation potentials at three sites, a reduced recruitment pattern, an increased incidence of polyphasic potentials and normal mean duration and amplitude of motor unit potentials. In the brachial biceps the only abnormality was a reduced recruitment pattern.

Motor and sensory conduction along distal and proximal segments of the radial and median nerves was normal, but the amplitude of the sensory potentials was markedly diminished. The maximal conduction velocity along the sural nerve was normal, but the amplitude of the sensory potential was diminished to $10 \%$ of normal (Fig. 2a). Neurological findings at 62 years of age were the same as at 57 years.

Biopsy of the sural nerve showed marked loss of large fibres ( $>7 \mu \mathrm{m}$ in diameter, Fig. $2 \mathrm{~b}$ ); the endoneurial area, the number of clusters of regenerating fibres and abnormalities among teased fibres were within the normal range; there was no demyelination (Fig. 2c).

The history of chronic exposure to lead, the increased lead excretion in the urine, the fall in haemoglobin concentration in the blood, and the repeated episodes of gastrointestinal symptoms common in chronic lead poisoning, make it likely that the neuropathy in Patient A was caused by lead poisoning. The reduced number of myelinated nerve fibres, the absence of demyelination, the marked decrease in the amplitude of the sensory potentials and the normal maximum and minimum conduction velocity indicate that the neuropathy was characterised by loss of axonal nerve fibres.

\section{Patient $B$}

This 47-year-old patient is included because, as he had been exposed to lead, his neuropathy was mis-
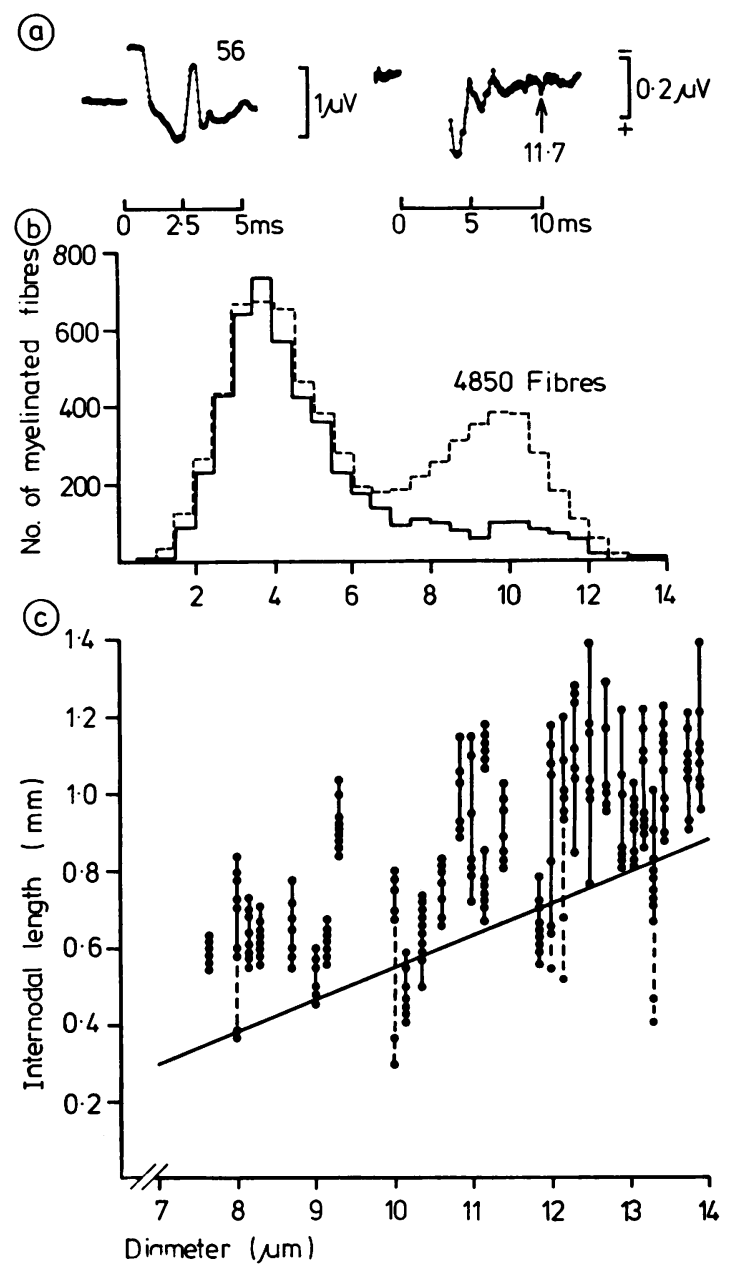

Fig. 2 Patient with lead neuropathy and with more than $150 \mu \mathrm{g}$ lead/100 ml blood. (a) Sensory potential of the sural nerve, evoked by a maximal stimulus at the lateral malleolus and recorded at midcalf; (left) the $90 \%$ diminished amplitude and the normal maximum conduction velocity (figures above the trace); (right) minimum conduction velocity (arrow and figures below the trace). (b) Histogram of diameter of myelinated fibres from the nerve of the patient (full line) and from controls (dashed line). Note the diminution in number of large fibres in the patient. (c) Internodal length as a function of maximum diameter of teased fibres, shown for 30 representative fibres. Normal segments are connected by full vertical lines, segments with segmental or paranodal remyelination (intercalated segments) by dashed lines. The oblique line is the lower $95 \%$ confidence limit of normal nerve. 
takenly diagnosed as being attributable to lead. In fact, he had a familial neuropathy with liability to pressure palsies (Behse et al., 1972). Six months after exposure to lead he had peroneal palsy, which improved, and four months later he suffered rightsided radial paralysis, which was unremitting. He had neither colic nor constipation. While he was exposed, determinations of lead in the blood were not available. The blood count was 4800 red cells per million with basophilic stippling and the haemoglobin concentration was normal. One year after exposure to lead the blood contained $33 \mu \mathrm{g}$ lead $/ 100 \mathrm{ml}$; the haemoglobin concentration was normal. Repeated interrogation elicited the information that both his father and his brother had a history of pressure palsy of the arm lasting for 3-4 months.

Neurological examination showed a markedly diminished force in some proximal and distal muscles of the upper extremities, less so in the legs with the exception of the extensor hallucis longus muscle which was severely paretic. Tendon jerks were absent in the arms, knee jerks were normal and ankle jerks were absent. Tactile sensibility was reduced in the area of the radial and the deep and superficial peroneal nerves. Perception of vibration was normal in the upper limbs and absent in the feet.

Electromyography in the left extensor digitorum communis, the left abductor pollicis brevis and the left abductor digiti quinti muscles showed fibrillation potentials at three sites, a reduced recruitment pattern, an increased incidence of polyphasic potentials $(20 \%)$, a normal mean duration and an increased amplitude of motor unit potentials. In the left anterior tibial muscle there was a discrete pattern of discharge during full effort, fibrillation potentials at three sites, $25 \%$ polyphasic potentials, $26 \%$ increased duration of motor unit potentials and $160 \%$ increased amplitude.

The maximum conduction velocity was slowed by $40 \%$ along motor and sensory fibres of the left peroneal and median nerves and along the fibres of the sural nerve (Fig. 3 (inset)). The slowing along the peroneal nerve was most marked across the capitulum fibulae consistent with a compression of the nerve at this site, also suggested by a pressure mark on the skin.

Biopsy of the sural nerve showed a reduced number of large myelinated fibres (Fig. 3a, b). Every teased fibre contained segments with regions of increased thickness of the myelin sheath ('sausages', Fig. 3c). Electron microscopy confirmed the excessive growth of the myelin sheath in these regions. In addition, every teased fibre showed evidence of deor remyelination.

The abnormalities in teased fibres are particularly indicative that, in Patient $B$, the increased level of

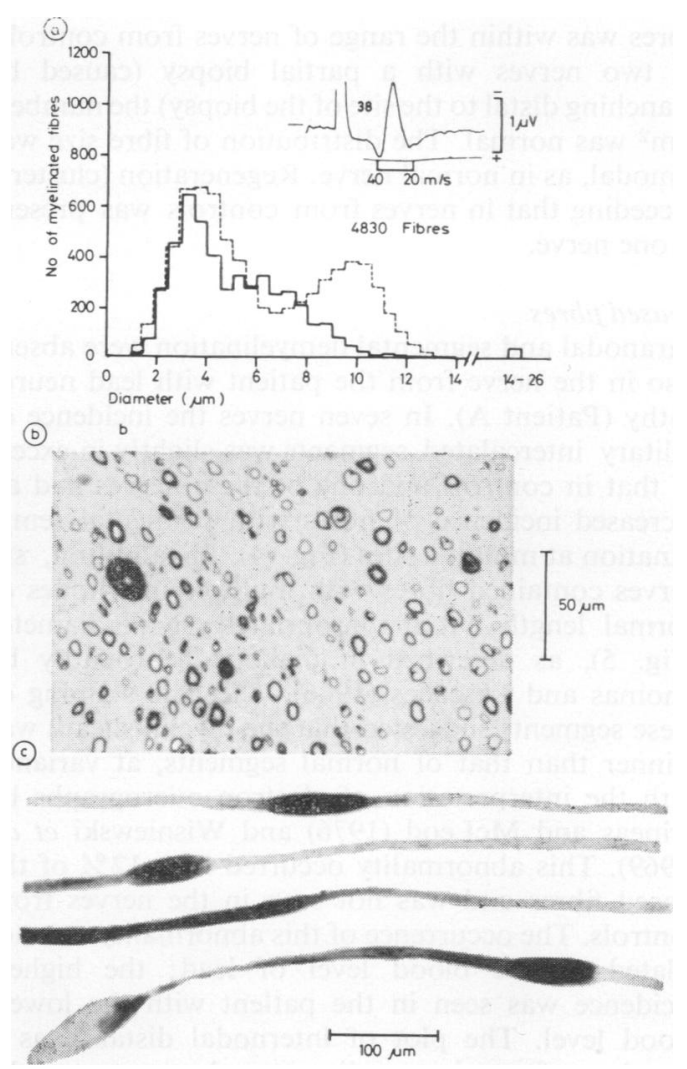

Fig. 3 Patient $B$, suspected to have lead neuropathy, who in fact had a hereditary neuropathy with liability to pressure palsies. Inset: Sensory potential evoked by maximal stimuli at the lateral malleolus and recorded at midcalf. The maximum conduction velocity (indicated by the figure above the trace) was $68 \%$ and the amplitude $15 \%$ of the normal average matched for age. (a) Distribution of diameter of myelinated nerve fibres in the sural nerve of the patient (full line) and in controls (dashed line). The number of large fibres was markedly diminished. (b) A representative sample of the cross-section. Note the fibre with a particularly thick myelin sheath, a large external diameter and a thin axon, probably cross-cut through a region with abnormal growth of the myelin sheath. (c) Teased fibres with regions of increased thickness of the myelin sheath.

lead in the blood was not related to his symptoms and signs.

\section{HISTOLOGICAL FINDINGS IN NERVES FROM LEAD-EXPOSED MEN}

Light microscopy, cross-sections

The endoneurial area was slightly increased in one nerve, but the number of large and small myelinated 
fibres was within the range of nerves from controls. In two nerves with a partial biopsy (caused by branching distal to the site of the biopsy) the number/ $\mathrm{mm}^{2}$ was normal. The distribution of fibre size was bimodal, as in normal nerve. Regeneration (clusters) exceeding that in nerves from controls was present in one nerve.

\section{Teased fibres}

Paranodal and segmental demyelination were absent also in the nerve from the patient with lead neuropathy (Patient A). In seven nerves the incidence of solitary intercalated segments was slightly in excess of that in controls and one of these nerves had an increased incidence of fibres with segmental remyelination at multiple sites (Fig. 4). In addition, six nerves contained fibres with multiple internodes of normal length but inappropriately small diameter (Fig. 5), as described in diabetic neuropathy by Thomas and Lascelles (1966). The pale staining of these segments suggested that the myelin sheath was thinner than that of normal segments, at variance with the interpretation of electron micrographs by Prineas and McLeod (1976) and Wisniewski et al. (1969). This abnormality occurred in $2-12 \%$ of the teased fibres and was not seen in the nerves from controls. The occurrence of this abnormality was not related to the blood level of lead; the highest incidence was seen in the patient with the lowest blood level. The plot of internodal distance as a function of maximum diameter demonstrates the

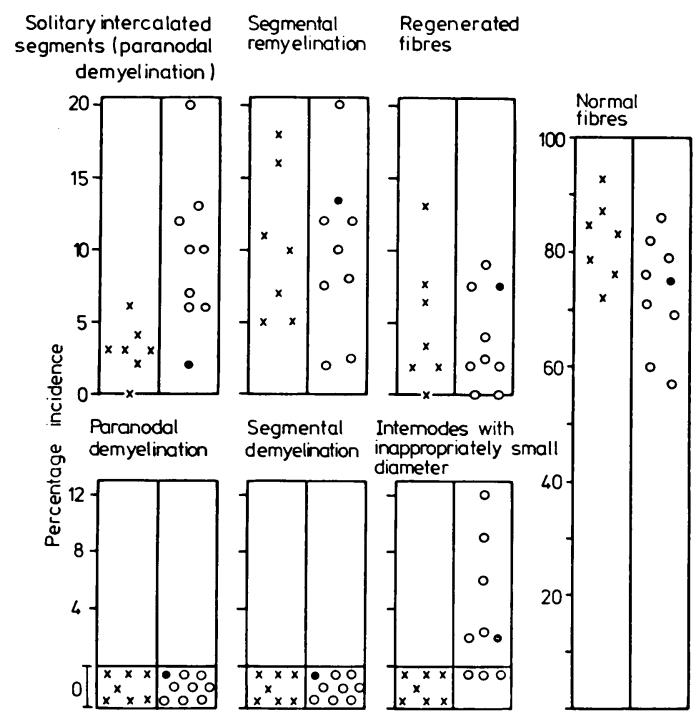

Fig. 4 Incidence of teased fibres with abnormalities from sural nerves of 8 lead-exposed men (O), of a patient with lead neuropathy $(\bullet)$ and of 7 controls $(\mathrm{X})$. slightly increased incidence of remyelinated segments (in most, paranodal remyelination). There were only few fibres with these abnormalities in the nerve from the patient with lead neuropathy (Fig. 4, solid circles and Fig. 2).

\section{Electron microscopy}

The area analysed in each nerve was $15 \times 10^{3} \mu \mathrm{m}^{2}$, sampled from three fascicles. The structure of the myelin sheath was normal. In two of the leadexposed men the nerve contained 302 and 408 bands of Büngner compared with, at most, 263 in nerves from controls.

The only abnormality among unmyelinated fibres was an increased incidence of fibres undergoing degeneration (Table 3). These fibres were characterised by loss of axonal organelles and sometimes by an increase in size (Dyck and Hopkins, 1972; Thomas, 1973; Behse et al., 1975). In the three nerves examined from lead-exposed men, this abnormality occurred in $2 \cdot 5-2.9 \%$ of the unmyelinated fibres, compared with at most $0.5 \%$ of five out of six nerves from controls and $1.8 \%$ in the sixth nerve. The number of unmyelinated fibres, their size distribution, the number of Schwann cell subunits devoid of unmyelinated fibres and the ratio of unmyelinated fibres per Schwann cell subunit were within the range found in controls.

\section{SENSORY CONDUCTION VELOCITY AND \\ DIAMETER OF THE LARGEST FIBRES}

The conduction velocity varies proportionately with the diameter of the nerve fibre (Gasser and Erlanger, 1927) and the maximum conduction velocity can be calculated from the diameter of the largest fibres (conversion factor $4 \cdot 3 \pm 0 \cdot 1$, Buchthal et al., 1975). The conduction velocities along the nerves of six lead-exposed men, and along the nerve of the patient with lead neuropathy, group about a line with slope 1 , indicating that the velocity calculated from the diameter of the largest fibres was equal to that determined from the sensory potential (Fig. 6). In the nerves of two lead-exposed men the velocity determined from the sensory potential was slightly lower than the velocity to be expected from the largest diameter, but the deviation was less than $20 \%$, the scatter in normal nerve. These findings indicate that the maximum conduction velocity, whether normal or borderline, was determined by the diameter of the largest fibres. This applied also to the nerve from the patient with lead neuropathy and is compatible with the absence of demyelination in teased fibres.

\section{Discussion}

The main result of the present study of a group of lead-exposed men, with a maximum level of lead in 
Fig. 5 Biopsy of the sural nerve from a man with a maximum level of lead in the blood of $50 \mu g / 100 \mathrm{ml}$. Three teased, continuous nerve fibres, each containing segments with normal length but inappropriately small diameter. In the case of fibres $A$ and $B$, portions of a segment of normal and of small diameter are shown at higher magnification $(a, b) ;$ in the case of fibre $C$ the more highly magnified portion $(c)$ contains both normal (left) and small diameter (right). The perpendicular arrows mark Ranvier nodes. The magnification is indicated by the scale at the bottom: it is $1 \mathrm{~mm}$ for $A, B$ and $C$ and $0.3 \mathrm{~mm}$ for $a, b$ and $c$.

the blood of $70-140 \mu \mathrm{g} / 100 \mathrm{ml}$, was a slight slowing in motor and sensory conduction velocity in some nerves of the upper and lower extremities in the absence of relevant histological abnormalities in the sural nerve. The slight slowing in conduction velocity and the slight abnormalities found in teased fibres of some of the sural nerves are without clinical significance, and without relevance to the health and well-being of the lead workers.

Our findings deviate in several respects from those in previous studies, which were considered to indicate subclinical neuropathy. Although blood levels of our subjects were similar to those measured by Catton et al. (1970), we rarely found the reduction in the ratio of the amplitude of the motor response evoked by stimulation of the peroneal nerve at the 
Table 3 Unmyelinated nerve fibres and Schwann cell subunits

\begin{tabular}{|c|c|c|c|c|c|}
\hline \multirow{2}{*}{$\begin{array}{l}\text { Sural nerve } \\
\text { Total no. of Schwann cell subunits }\end{array}$} & \multirow{2}{*}{$\begin{array}{l}\text { Lead } \\
\text { neuropathy } \\
25900\end{array}$} & \multicolumn{2}{|c|}{ Lead-exposed men* } & \multicolumn{2}{|r|}{ Controls (6) } \\
\hline & & 24301 & $\begin{array}{l}12362 \\
21314 / \mathrm{mm}^{2}\end{array}$ & 20588 & $\begin{array}{l}13800-31500 \\
19000-57000 / \mathrm{mm}^{2}\end{array}$ \\
\hline No. of Schwann cell subunits containing axons & 22400 & 20674 & $\begin{array}{l}10971 \\
18916 / \mathrm{mm}^{2}\end{array}$ & 17123 & $\begin{array}{l}12600-29300 \\
13700-34000 / \mathrm{mm}^{2}\end{array}$ \\
\hline No. of Schwann cell subunits devoid of axons & 3500 & 3627 & $\begin{array}{l}1428 \\
2462 / \mathrm{mm}^{2}\end{array}$ & 3465 & $\begin{array}{l}900-5700 \\
1200-5400 / \mathrm{mm}^{2}\end{array}$ \\
\hline No. of unmyelinated fibres & 29000 & 28472 & $\begin{array}{l}16870 \\
29086 / \mathrm{mm}^{2}\end{array}$ & 26397 & $\begin{array}{l}20100-37500 \\
18962-57692 / \mathrm{mm}^{2}\end{array}$ \\
\hline $\begin{array}{l}\text { No. of axons per Schwann cell subunit } \\
\text { No. of degenerating fibres }\end{array}$ & $\begin{array}{l}1 \cdot 29 \\
0\end{array}$ & $833^{1 \cdot 38}$ & $\begin{array}{l}1 \cdot 54 \\
414 \\
713 / \mathrm{mm}^{2}\end{array}$ & $713^{1 \cdot 56}$ & $\begin{aligned} 1.24- & 1.85 \\
0- & 362 \\
0- & 342 / \mathrm{mm}^{2}\end{aligned}$ \\
\hline $\begin{array}{l}\% \\
\text { No. of Schwann cell nuclei }\end{array}$ & $\begin{array}{r}0 \\
4430\end{array}$ & 2539 & $\begin{array}{ll} & 2 \cdot 5 \\
1 & 353 \\
2 & 333 / \mathrm{mm}^{2}\end{array}$ & 1733 & $\begin{array}{c}0 \cdot 5-1 \cdot 1 \cdot 8 \\
900-2980 \\
1000-3400 / \mathrm{mm}^{2}\end{array}$ \\
\hline $\begin{array}{l}\text { Mean diameter of unmyelinated fibres }(\mu \mathrm{m}) \\
\operatorname{SD}(\mu \mathrm{m})\end{array}$ & $\begin{array}{r}1 \cdot 03 \\
0 \cdot 35\end{array}$ & $\begin{array}{r}1.03 \\
0.25\end{array}$ & $\begin{array}{r}1 \cdot 13 \\
0 \cdot 33 \\
29\end{array}$ & $\begin{array}{r}1.02 \\
0.30\end{array}$ & $\begin{array}{lr}0.99- & 1.28 \\
0.28- & 0.50\end{array}$ \\
\hline No. of fibres $<0.8 \mu \mathrm{m} \quad$ SD (\%) & $9 \begin{array}{r}34 \\
180\end{array}$ & $\begin{array}{r}24 \\
4840\end{array}$ & $\begin{array}{l}29 \\
2328 \\
4014 / \mathrm{mm}^{2}\end{array}$ & $\begin{array}{r}29 \\
6217\end{array}$ & 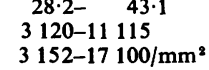 \\
\hline $\begin{array}{l}\% \\
\text { No. of fibres }>1.4 \mu \mathrm{m}\end{array}$ & $\begin{array}{l}31 \cdot 6 \\
2695\end{array}$ & $\begin{array}{r}17 \\
1480\end{array}$ & $\begin{array}{l}13.8 \\
4437 \\
7650 / \mathrm{mm}^{2}\end{array}$ & $\begin{array}{r}24 \\
2344\end{array}$ & $\begin{array}{l}10 \cdot 7-31 \cdot 7 \\
1913-9121 \\
2943-9213 / \mathrm{mm}^{2}\end{array}$ \\
\hline$\%$ & $9 \cdot 3$ & $5 \cdot 2$ & $26 \cdot 3$ & $9 \cdot 0$ & $5 \cdot 1-\quad 31 \cdot 2$ \\
\hline
\end{tabular}

* Partial biopsy with endoneurial area of $0.58 \mathrm{~mm}^{2}$. Therefore, in addition, the number $/ \mathrm{mm}^{2}$ is shown under the total number of each component.

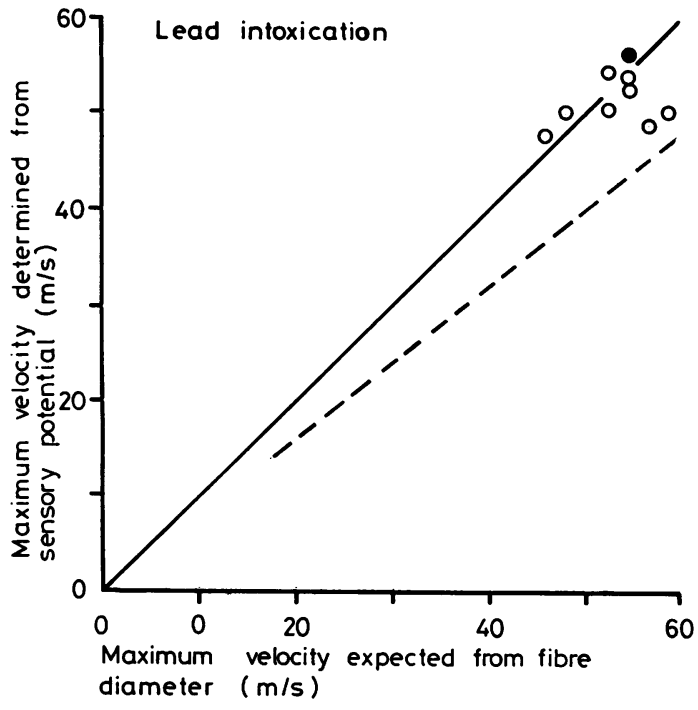

Fig. 6 Maximum conduction velocity along the sural nerve, determined from the sensory potential as a function of the velocity predicted from the diameter of the largest myelinated fibres. Lead-exposed men $(O)$ and patient with lead neuropathy (O). Velocities were grouped about the solid line with slope 1 , intercept 0 , or were within $20 \%$ of the expected velocity (dashed line, scatter in normal nerves).

knee and at the ankle that was present in 13 of 19 subjects studied by those authors. On the other hand, they, like us, found normal maximum motor and sensory conduction velocity along the peroneal nerve.
Unlike the finding of Araki and Homma (1976), the maximum conduction velocity in our subjects was not related to the maximum or to the average level of lead in the blood.

In a group of 26 lead-exposed subjects examined by Seppäläinen et al. (1975) slowing was confined to motor fibres of the ulnar and median nerve. The velocity along the sensory nerves of the arms and the legs was normal, whereas it, too, was slightly slow in the group of men we studied. We did not measure conduction along the ulnar nerve because this nerve so often suffers damage at the elbow (Payan, 1969; Neary et al., 1975), which may manifest itself only as slight slowing in conduction distal to the elbow. Seppäläinen et al. (1975) place particular emphasis on the slowing along 'slower fibres', determined from the minimum time required to prevent impulse collision by two stimuli (Hopf, 1962). The validity of this method is debatable; the results in normal nerve suggest that no fibres are more than 15-20\% slower than the fastest fibres, whereas the range of velocities found by another collision technique in man (Thomas et al., 1959) and in the baboon (Gilliatt et al., 1976) was twice as large.

Electromyographical findings also differed from those reported by Seppäläinen et al. (1975). They found abnormalities in nine of 11 subjects examined, five of whom had fibrillation potentials. None of the 40 muscles examined in our subjects showed fibrillation potentials or loss of motor units during full effort. Abnormalities, when present, were discrete and confined to the anterior tibial muscle; diagnostic importance cannot be attached to them. On the other hand, marked electromyographic abnormalities were present in most of 10 patients 
with clinical evidence of lead neuropathy reported by Hausmanowa-Petrusewicz et al. $(1962,1967)$ and in the patient whom we examined.

The only relevant abnormality that could be demonstrated in eight of 20 subjects was the prolonged latency from the ankle to the extensor digitorum brevis muscle, probably caused by local compression of the deep peroneal nerve at the dorsum pedis by metal-lined safety shoes. The shoes were worn by all men during work and often at home; the shoe weighed $700 \mathrm{~g}$, nearly twice as much as an ordinary wooden shoe. It caused sustained pressure marks on the dorsum of the feet and on the big toes in subjects with prolonged distal latency and in 19 of 50 other subjects whose feet were examined but in whom distal motor latency was not determined.

The electrophysiological and the histological changes in lead-exposed men were different in type from those in patients with clinical evidence of lead neuropathy (Simpson et al., 1964; Delwaide and Chantraine, 1965; Buchthal et al., 1975) and in experimental lead poisoning in baboons (blood levels $100-1000 \mu \mathrm{g} / 100 \mathrm{ml}$ ) followed for up to one year (Hopkins, 1970). In lead neuropathy the histological changes indicated axonal degeneration, resulting in a reduction in conduction velocity that corresponded to the loss of large fibres, and in an extremely diminished amplitude of the sensory potentials. Loss of large fibres was also the main pathological feature in previous case reports of lead neuropathy (Gombault, 1873; Déjerine, 1879; Laslett and Warrington, 1898; Hopkins, 1970; Goldstein et al., 1975). Segmental demyelination produced by chronic lead poisoning in guinea pigs (Gombault, 1880-81; Fullerton, 1966) was virtually absent in our patient with lead neuropathy, in the lead-poisoned baboons and in the eight lead-exposed men with raised blood lead levels from whom a nerve biopsy was obtained (maximum blood lead levels $50-90 \mu \mathrm{g} / 100$ $\mathrm{ml})$.

The slight slowing in conduction velocity along some of the nerves of the lead-exposed men was associated neither with loss of large myelinated fibres nor with a diminution in amplitude of the sensory or motor evoked potentials. On the contrary, the average amplitude of the sensory potentials was even increased in some nerves. The cause of the increase in amplitude is obscure; it is unexpected because the greater temporal dispersion attributable to slowing usually leads to a diminished amplitude. However, the amplitude of the terminal positive phase of the component potentials is an essential variable in the summation to the compound potential. If the terminal positive phase is diminished, the peak-to-peak amplitude increases (Buchthal and Rosenfalck, 1966).
In addition, the abnormalities in teased fibres were minor. The slight increase in fibres with paranodal remyelination was more marked in the lead-exposed men than in the patient with lead neuropathy. Some teased fibres had several long internodes with inappropriately small diameter. They occurred more frequently in the lead-exposed men than in the nerve of the patient with lead neuropathy. Whether these thin internodes reflect the onset of primary demyelination (Prineas and McLeod, 1976) or mark the onset of axonal damage (Dyck et al., 1971) is not known.

As there was neither axonal degeneration nor changes in the myelin sheath to account for the slowing, it was considered to be attributable to a slight change in the properties of the nodal membrane that prolonged the time during which the transmembrane potential increased (Behse and Buchthal, 1978).

There was no dose-effect relationship in the incidence of histological abnormalities or in the incidence and degree of electrophysiological abnormalities. The slowing in conduction was independent of the maximal blood lead level, which varied from 50 to $140 \mu \mathrm{g} / 100 \mathrm{ml}$ in the different subjects. This is at variance with the assumption of the Second International Workshop on Permissible Levels for Occupational Exposure to Inorganic Lead (Zielhuis, 1977). The slowing was also independent of the average blood lead level and of time of exposure to lead, which varied from few months to 33 years Thus, the mechanism of the lesion that caused the electrophysiological changes in the lead-exposed men seemed to have major differences from that in lead neuropathy and it is doubtful whether the slight slowing in conduction should be considered to constitute subclinical neuropathy.

\section{Acknowledgements}

We are indebted to the staff of the Department of Neurosurgery, Rigshospital, Copenhagen, for performing the sural biopsies. We thank Dr F. Carlsen, Copenhagen, for help with electron microscopy, Dr J. Nyboe, Copenhagen, for help with the statistical treatment of the data and Dr Pamela M. Le Quesne, London, for helpful criticism in the preparation of the manuscript. We acknowledge the assistance of the International Lead Zinc Research Organization, Inc, New York, for compensating volunteers for income lost during their participation in the study.

\section{References}

Araki, S., and Homma, T. (1976). Relationships between lead absorption and peripheral nerve conduction velocities in lead workers. Scandinavian Journal of Environment and Health, 4, 225-231.

Behse, F., and Buchthal, F. (1971). Normal sensory con- 
duction in the nerves of the leg in man. Journal of Neurology, Neurosurgery and Psychiatry, 34, 404-414.

Behse, F., and Buchthal, F. (1977). Peroneal muscular atrophy (PMA) and related disorders. II. Histological findings in sural nerves. Brain, 100, 67-85.

Behse, F., and Buchthal, F. (1978). Sensory action potentials and biopsy of the sural nerve in neuropathy. Brain, 101, 473-493.

Behse, F., Buchthal, F., Carlsen, F., and Knappeis, G. G. (1972). Hereditary neuropathy with liability to pressure palsies. Brain, 95, 777-794.

Behse, F., Buchthal, F., Carisen, F., and Knappeis, G. G. (1974). Endoneurial space and its constituents in the sural nerve of patients with neuropathy. Brain, 97, 773-784.

Behse, F., Buchthal, F., Carlsen, F., and Knappeis, G. G. (1975). Unmyelinated fibres and Schwann cells of sural nerve in neuropathy. Brain, 98, 493-510.

Bender, M. B. (1952). Disorders in Perception (With Particular Reference to Phenomena of Extinction and Displacement). Charles C. Thomas: Springfield, Illinois.

Bender, M. B. (1970). Perceptual interactions. In Modern Trends in Neurology, Volume 5, pp. 15, 17. Edited by D. Williams. Butterworth: London.

Buchthal, F. (1957). In An Introduction to Electromyography, pp. 22-26. Gyldendal: Copenhagen.

Buchthal, F., and Rosenfalck, A. (1966). Evoked action potentials and conduction velocity in human sensory nerves. Brain Research, 3, 1-122.

Buchthal, F., and Rosenfalck, A. (1971). Sensory potentials in polyneuropathy. Brain, 94, 241-262.

Buchthal, F., Rosenfalck, A., and Behse, F. (1975). Sensory potentials of normal and diseased nerves. In Peripheral Neuropathy, Volume 1, pp. 442-464. Edited by P. J. Dyck, P. K. Thomas and E. H. Lambert. W. B. Saunders: Philadelphia.

Catton, M. J., Harrison, M. J. G., Fullerton, P. M., and Kazantzis, G. (1970). Subclinical neuropathy in lead workers. British Medical Journal, 2, 80-82.

Cernik, A. A. (1974). Determination of blood lead using a 4 mm paper punched disc carbon sampling cup technique. British Journal of Industrial Medicine, 31, 239-244.

Cernik, A. A., and Sayers, M. H. P. (1971). Determination of lead in capillary blood using a paper punch disc atomic absorption technique. British Journal of Industrial Medicine, 28, 392-398.

Dahl, K., and Buchthal, F. (1978). Digital memory recorder in electromyography and nerve conduction studies. Journal of Electroencephalography and Clinical Neurophysiology, 45, 538-544.

Delwaide, P. J., and Chantraine, J. M. (1965). Participation spinale dans l'intoxication saturnine: arguments électromyographiques. In Proceedings of the Sixth International Congress of Electroencephalography and Clinical Neurophysiology, Vienna, September 5-10, 1965, pp. 643-646. Vienna Academy of Medicine: Vienna.

Déjerine, J. (1879). Recherches sur les lésions du sytèmes nerveux dans la paralysie saturnine. Comptes Rendus de la Societé de Biologie (Paris), 7th series, 1, 11-17.

Dyck, P. J., and Hopkins, A. P. (1972). Electron microscopic observations on degeneration and regeneration of unmyelinated fibres. Brain, 95, 223-234.

Dyck, P. J., Johnson, E. W., Lambert, E. H., and O'Brien, P. C. (1971). Segmental demyelination secondary to axonal degeneration in uremic neuropathy. Proceedings of Staff Meetings of the Mayo Clinic, 46, 400-431.

Fernandez, F. J. (1975). Micromethod for lead determination in whole blood by atomic absorption, with use of the graphite furnace. Clinical Chemistry, 21, 558-561.

Fisher, R. A. (1944). Statistical Methods for Research
Workers, 9th edition. Oliver and Boyd: Edinburgh and London.

Fullerton, P. M. (1966). Chronic peripheral neuropathy produced by lead poisoning in guinea-pigs. Journal of Neuropathology and Experimental Neurology, 25, 214-236.

Gasser, H. S., and Erlanger, J. (1927). The role played by the size of the consituent fibre of a nerve trunk in determining the form of its action potential wave. American Journal of Physiology, 80, 522-547.

Gilliatt, R. W., Hopf, H. C., Rudge, P., and Baraitser, M (1976). Axonal velocities of motor units in the hand and foot muscles of the baboon. Journal of the Neurological Sciences, 29, 249-258.

Goldstein, N. P., McCall, J. T., and Dyck, P. J. (1975) Metal neuropathy. In Peripheral Neuropathy, Volume 2, pp. 1240-1249. Edited by P. J. Dyck, P. K. Thomas and E. H. Lambert. W. B. Saunders: Philadelphia.

Gombault, A. (1873). Contribution à l'histoire anatomique de l'atrophie musculaire saturnine. Archives de Physiologie Normale et Pathologique, 5, 592-597.

Gombault, M. (1880-1881). Contribution à l'étude anatomique de la névrite parenchymateuse subaiguë et chronique. Névrite segmentaire péri-axile. Archives de Neurologie (Paris), 1, 11-38; 177-190.

Hausmanowa-Petrusewicz, I., Emeryk, B., Sobkawicz, H., Wasowicz, B., and Tur, J. (1962). Electromyographic records in lead poison!ng. Polski Tygodnik Lekarski, 17, 1405-1408. (Polish, cited from the English summary.)

Hausmanowa-Petrusewicz, I., Emeryk, B., Wasowicz, B., and Kopeć, A. (1967). Electromyography in neuro-muscular diagnostics. Electromyography, 7, 203-225.

Hopf, H. C. (1962). Untersuchungen über die Unterschiede in der Leitgeschwindigkeit motorischer Nervenfasern beim Menschen. Deutsche Zeitschrift für Nervenheilkunde, 183, 579-588.

Hopkins, A. (1970). Experimental lead poisoning in the baboon. British Journal of Industrial Medicine, 27, 130140.

Lane, R. E., et al. (1968). Diagnosis of inorganic lead poisoning: a statement. British Medical Journal, 4, 501.

Laslett, E. E., and Warrington, W. B. (1898). The morbid anatomy of a case of lead paralysis. Condition of the nerves, muscles, muscle spindles and spinal cord. Brain, 21, 224-231.

Matson, W. R., Roe, D. K., and Carritt, D. E. (1965). Composite graphite-mercury electrode for anodic stripping voltammetry. Analytical Chemistry, 37, 1594-1595.

Neary, D., Ochoa, J., and Gilliatt, R. W. (1975). Subclinical entrapment neuropathy in man. Journal of the Neurological Sciences, 24, 283-298.

Payan, J. (1969). Electrophysiological localization of ulnar nerve lesions. Journal of Neurology, Neurosurgery and Psychiatry, 23, 208-220.

Pierce, J. O., Koirtyohann, R. S., Clevenger, T. E., and Lichte, R. E. (1976). The Determination of Lead in Blood. A Review and Critique of the State of the Art, 1975, pp. 10, 23, 27,28 . International Lead and Zinc Research Organization, Inc: New York.

Prineas, J. W., and McLeod, J. G. (1976). Chronic relapsing polyneuritis. Journal of the Neurological Sciences, 27, 427458.

Rosenfalck, A., and Rosenfalck, P. (1975). Electromyography -Sensory and Motor Conduction: Findings in Normal Subjects, pp. 3, 4, 10, 11, 20, 22-25. Laboratory of Clinical Neurophysiology, Rigshospital, Copenhagen.

Seppäläinen, A. M., and Hernberg, S. (1972). Sensitive technique for detecting subclinical lead neuropathy. British Journal of Industrial Medicine, 29, 443-449.

Seppäläinen, A. M., Tola, S., Hernberg, S., and Kock, B. 
(1975). Subclinical neuropathy at "safe" levels of lead exposure. Archives of Environmental Health, 30, 180-183.

Simpson, J. A., Seaton, D. A., and Adams, J. F. (1964). Response to treatment with chelating agents of anaemia, chronic encephalopathy, and myelopathy due to lead poisoning. Journal of Neurology, Neurosurgery and Psychiatry, 27, 536-541.

Thomas, P. K. (1973). The ultrastructural pathology of unmyelinated nerve fibres. In New Developments in Electromyography and Clinical Neurophysiology, Volume 2, pp. 227-239. Edited by J. E. Desmedt. S. Karger: Basel.

Thomas, P. K., and Lascelles, R. G. (1966). The pathology of diabetic neuropathy. Quarterly Journal of Medicine, 35, 489-509.

Thomas, P. K., Sears, T. A., and Gilliatt, R. W. (1959). The range of conduction velocity in normal motor nerve fibres to the small muscles of the hand and foot. Journal of Neurology, Neurosurgery and Psychiatry, 22, 175-181.
US Department of Health, Education and Welfare (1977). Lead in blood, physical and chemical analytical method no. 195. In Manual of Analytical Methods, 2nd edition, Volume 1. Public Health Center of Disease Control, National Institute for Occupational Safety and Health: Cincinnati, Ohio, USA.

Wagner, A. L., and Buchthal, F. (1972). Motor and sensory conduction in infancy and childhood: a reappraisal. Developmental Medicine and Child Neurology, 14, 189-216.

Wisniewski, H., Prineas, J., and Raine, C. S. (1969). An ultrastructural study of experimental demyelination and remyelination. Part I. (Acute experimental allergic encephalomyelitis in the peripheral nervous system). Laboratory Investigation, 21, 105-118.

Zielhuis, R. L. (1977). Second International Workshop on Permissible Levels for Occupational Exposure to Inorganic Lead. International Archives of Occupational and Environmental Health, 39, 59-72.

\section{The February 1979 issue}

\section{THE FEBRUARY 1979 ISSUE CONTAINS THE FOLLOWING PAPERS}

Dependence of acoustic attenuation of hearing protectors on incident sound level A. M. MARTIN

The mortality of men in the Rhondda Fach, 1950 1970 A. L. COCHRANE, T. J. L. HALEY, F. MOORE, AND D. HOLE

Radiological changes after withdrawal from asbestos exposure M. R. BECKLAKE, F. D. K. LIDDELL, J. MANFREDA, AND J. C. MCDONALD

Pulmonary function in firefighters: acute changes in ventilatory capacity and their correlates A. W. MUSK, T. J. SMITH, J. M. PETERS, AND E. MCLAUGHLIN

Histamine release from platelets for assay of byssinogenic substances in cotton mill dust and related materials S. K. AINSWORTH, R. E. NEUMAN, AND R. A. HARLEY
Squamous cell skin cancer in the North-west of England, 1967-69, and its relation to occupation C. J. WHITAKER, W. R. LEE, AND J. E. DOWNES

Occupational lead exposure in Denmark: screening with the haematofluorometer P. GRANDJEAN

Bromine in blood, EEG and transaminases in methyl bromide workers M. M. VERBERK, T. ROOYAKKERS-BEEMSTER, M. DE VLIEGER, AND A. G. M. VAN VLIET

Dimethylformamide and alcohol intolerance W. H. LYLE, T. W. M. SPENCE, W. M. MCKINNELY, AND K. DUCKERS

Book reviews

\section{Notices}

Information section

Copies are still available and may be obtained from the PUBLISHING MANAGER, BRITISH MEDICAL ASSOCIATION, TAVISTOCK SQUARE, LONDON WC1H 9JR, price $£ 4.25$ (USA $\$ 9.20$ ), including postage 